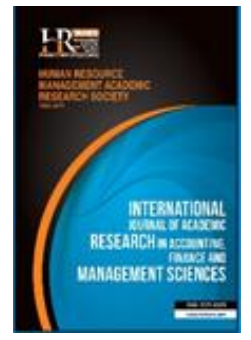

International Journal of Academic Research in Accounting, Finance and Management Sciences

Vol. 8, No.4, October 2018, pp. 195-203

E-ISSN: 2225-8329, P-ISSN: 2308-0337

(C) 2018 HRMARS

www.hrmars.com

To cite this article: ljeoma, M. M., Ezeamama, M., Ebisi, L. N. E. (2018). Economic Policy Management in Nigeria: Effective Diversification Approaches, International Journal of Academic Research in Accounting, Finance and Management Sciences 8 (4): 195-203.

\title{
Economic Policy Management in Nigeria: Effective Diversification Approaches
}

\author{
Marire Mary ljeoma ${ }^{1}$, Martin Ezeamama², Lilian Njideka Ebisi ${ }^{3}$ \\ ${ }^{1}$ Department of Business Administration, Enugu State University of Sciences and Technology, Enugu \\ ${ }^{2}$ Department of Banking and Finance, Spiritan University Isuochi, Abia State \\ ${ }^{3}$ Department of Accountancy, Airforce Institute of Technology, Mando, \\ E-mail: mariremary@gmail.com (Corresponding author)
}

\begin{abstract}
The study examined effective approaches to diversifying policy management: The way forward. This paper examined the various approaches to diversifying policy management in Nigeria. The study also examines the effect of diversifying policy management on the development of Nigeria economy. The population consists of 562 employees of Dangote group of company in Enugu State. The study used the survey approach. The primary sources used were used to administer 290 copies of questionnaire to the sampled staff of Dangote Groups in Enugu, 282 were returned and accurately filled. The validity of the instrument was tested using content analysis and the result was good. The reliability was tested using the Pearson correlation coefficient (r). It gave a reliability co-efficient of 0.87 which was also good. The hypotheses were analyzed using $f$-statistics (ANOVA). The study shows that diversifying policy management plays significant role in the development of Nigeria economy. Economic diversification is the process of expanding the range of economic activities both in the production and distribution of goods and services. The study recommends that different sections of the nation and tiers of government should develop other aspects of economy where they have comparative advantage. Efforts should accommodate the key requirements of sustainable development which include meeting the basic needs of man (job, food, health, clothing and shelter), maintaining equity both within and between generations, improving on technology and social organisation to expand the environmental ability to sustain human needs.
\end{abstract}

Key words

Diversification, Economic Growth, Gross Domestic Product, Environment

Received: 05 Nov $2018 \quad$ C) The Authors 2018

Revised: 26 Dec 2018 Published by Human Resource Management Academic Research Society (www.hrmars.com

Accepted: 10 Jan 2019 This article is published under the Creative Commons Attribution (CC BY 4.0) license. Anyone may Published Online: 16 Jan 2019 reproduce, distribute, translate and create derivative works of this article (for both commercial and noncommercial purposes), subject to full attribution to the original publication and authors. The full terms of this license may be seen at: http://creativecommons.org/licences/by/4.0/legalcode

\section{Introduction}

\subsection{Background of the Study}

Diversification is a risk management technique that mixes a wide variety of investments within a portfolio. The rationale behind this technique contends that a portfolio constructed of different kinds of investments will, on average, yield higher returns and pose a lower risk than any individual investment found within the portfolio.

A survey of the international scene of developing countries shows that governments of various Less Developed Countries (LDCs) have engaged in varieties of strategies and programmes in order to develop their economies and achieve sustainable growth. These programmes are referred to, in economic parlance, as 'instruments of national policy. They include the establishment of public organizations that take different 
legal and organizational structures, different managerial patterns and different sets of relationships with governments to understand and to review the different means by which they can achieve sustainable development in their countries with the limited resources at their disposal. The global financial and economic crisis has revealed Africa's vulnerability to external economic shocks because of Africa's effort to meet the millennium development goals by 2015.

Economic diversification which demands active participation in wide range of sectors, and firmly integrated into different regions, are better able to generate robust growth and great potential to increase Africa's resilience and contribute to achieving and sustaining long economic growth and development in the continent. A strong growing sustainable economy is the goal of every nation in the world. However, scholars agree that economic development has been very slow on the African continent. Adebayo (2012) notes: Despite its riches, African countries have not been very successful in wooing investors to the continent. A significant bottleneck for economic development in many countries of the region is its poor physical infrastructure. Essential services such as electric power, water, roads, railways, ports, and communications have been neglected, especially in the rural areas. The most important things to reiterate about the region's economy are that it remains undeveloped and is becoming increasingly marginalized in a competitive global economy where other developing regions are making the fastest headway. Africa continues to rely on exporting primary commodities. It cannot generate enough investment capital from within and is largely failing to attract foreign investments.

Nigeria is the most populated African nation with a population of about 160 million. The nation is made up of people of diverse cultures and religions. She is endowed with many natural resources scattered in different parts of the territory. At independence in 1960, the main source of the nation's revenue was agriculture and extraction of solid minerals. The discovery of petroleum in the country in the 1960s and the blooming of petroleum in the global market led to her over dependence on petroleum and a gradual but consistent neglect of agriculture and other sectors of the economy. Today petroleum accounts for over $90 \%$ of Nigeria's export revenue and over $80 \%$ of the government's budget (Jekwe, n.d.). Most of this petroleum revenue has been mismanaged through corruption, and disoriented, myopic and short term economic programmes. It is unfortunate that the different tiers of government in Nigeria cannot pay their workers talk less of embarking on any meaningful project without reliance on petroleum revenue.

Without exaggerating, it is a well-known fact that Nigeria ranks among the most richly endowed nations of the world in terms of natural, mineral and human resources. Nigeria has a variety of both renewable and non-renewable resources, some of which have not yet been effectively tapped. Solar energy, probably the most extensive of the underutilized renewable resources, is likely to remain untapped for some time, and the vast reserves of natural gas produced with crude oil have yet to be fully utilized (Limited and Akpan, 2015).

Before the discovery of oil in 1956 in Nigeria, Nigeria was famous in her agrarian economy through which cash crops like palm produce, cocoa, rubber, timber, ground nuts, were exported, thus making Nigeria a major exporter in that respect. Also, Nigeria had 19 million heads of cattle, the largest in Africa. At present, Nigeria is no longer a major producer of groundnuts (peanuts), rubber, and palm oil. Cocoa production, mostly from obsolete varieties and overage trees, has nevertheless increased from around 180,000 tons annually to 350,000 tons.

Undoubtedly, the discovery of crude oil has contributed and assisted Nigeria's economic prosperity and growth. Nevertheless, the current dwindling in oil price since June 2014, after five years of oil windfall, has immensely affected the economy of major oil exporters like Nigeria, Saudi Arabia, Iraq and Libya, etc. as was majorly aggravated by Middle East unrest and wars. Another huge blow to crude oil exporters was America's reduction in the number of barrels they import from nations. These factors have created a bad market for Nigeria and thus, her economy is presently shaking. This scenario is worsening by Nigeria's running mono-economic economy and the abandonment of agriculture.

Thus today, agriculture has suffered from long years of neglect, mismanagement, inconsistent and poorly conceived government policies, lack of government meaningful incentive to farmers, lack of basic infrastructure and a lot of bureaucratic bottlenecks in executing policies and agricultural programmes among government agencies (Brown, 2014). This paper however, seeks to evaluate the effective approaches to diversifying policy management: The way forward. 


\subsection{Problem Statement}

A careful observer notices that the oil boom which would have been an enduring blessing to Nigeria has regrettably necessitated great shift of attention to oil money, which resulted to a total neglect of agriculture.

The adverse effect of this boom and euphoria led to the establishment of new urban cities that necessitated mass exodus of able-bodied men and women from the rural areas to the cities in search of white-collar jobs and quick money. This development drastically reduced interest in agriculture and agrarian economy. Agricultural sector has been the leading provider of employment in Nigeria since the sixties and seventies, when the sector provided employment for more than 70 percent of the Nigerian population.

Unfortunately, in the wake of oil discovery, the attention on this sector of the economy was gradually and myopically shifted to the oil sector where employment opportunities were very low and the traditional agricultural exports have been on a progressive decline. Regrettably, the scenario has given rise to acute unemployment as oil sector could only employ limited number of the population and worse still, only experts.

\subsection{Objective of the Study}

The aim of this seminary paper is examine the effective approaches to diversifying policy management: The way forward. Specifically, the objectives of this study include;

1. To examine the various approaches to diversifying policy management in Nigeria.

2. To examine the effect of diversifying policy management on the development of Nigeria economy.

\subsection{Research Questions}

1. What are the various approaches to diversifying policy management in Nigeria?

2. To what extent does diversifying policy management affect the development of Nigeria economy?

\subsection{Research Hypotheses}

1. There are no qualitative approaches to diversifying policy management in Nigeria.

2. Diversifying policy management does not play any significant role on the development of Nigeria economy.

\subsection{Significance of the Study}

It is important to point out that on completion of this work by the researcher, it would be of immense significance to the following:

Business Operators: It is no doubt that the result of this study will be of help business operators in Nigeria as it will recommend the possible approaches to diversification.

Government: The result will also help policy makes to review their policies that will encourage diversification of business in Nigeria which will improve the national output and thereby nation income.

Researchers: Other researcher on this same or similar topic would find this work helpful as it will form a base of review of related literature and also a stepping stone for future researchers.

\section{Literature review}

\subsection{Concept of Economic Diversification and Sustainable Development}

Economic diversification is a process of broadening the range of economic activities both in the production and distribution of goods and services. It does not necessarily entail increase in output but it enhances stabilization of economies by diversifying their economic base. The issue of economic diversification should be viewed from the perspective of sustainable development to ensure long-term stability of the economy. Viewed from this angle, it has the capacity to fundamentally strengthen an economy's adaptive capacity and safeguards its long-term prospects in the face of depletion of the basic 
natural resources and the vagaries of economic fluctuations under the pressure of competition in globalization.

Economic diversification has the propensity to meet the basic requirement for sustainable development like meeting the poor's basic needs which revolves around provision of job, food, health, clothing and shelter by opening diverse avenues of economic activity which accommodates broad spectrum of people. It also propels the expansion of environmental ability to meet people's needs by improving the technology, social organization, diversity of areas of economic activity and not over exploiting one aspect of natural resources to the point of extinction and environmental degradation. Again, it creates a broad based economy that has the ability to secure equity both within and between generations (Zhang. n.d.).

\section{Challenges of Economic Diversification in Nigeria}

Nigerian government has made some efforts in the diversification of the economy. But government policies in this area have not been effective due to a number of challenges which include: macroeconomic orientation, poor infrastructure, weak economic institutions, poor corporate governance, poor educational orientation, endemic corruption and insecurity.

\section{Macroeconomic Orientation}

The nation's economy does not emphasis productivity. It emphasizes sharing of wealth and who gets what. This orientation is deepened in the nation's psyche by the easy revenues gotten from extraction of natural resources, especially petroleum. There is a dearth in investment of resources on long term productive ventures. Loans from both government and private sectors operate on high interest rate and can only be economically used for only short term projects. Hence, most of the loaned funds are used for trading (especially importation) which involves high turnover. This affects investing on the industrialization of the economy. Again, most of the nation's revenue revolves around the political class who wastes it on luxurious life style and patronage of foreign goods. This accounts for the government's waste of resources on bogus white elephant projects that are never finished and when finished cannot be maintained. The main stream of the economy, the business and working class, is deprived of the necessary resources to encourage skill acquisition, industrialization and productivity. Nigerian political office holders are among the highest paid while her workers are among the list paid in the world. Hence, her professionals and other elites abandon their areas of specialization and either juggle for political positions or leave the country for a better condition of service. There is urgent need for the nation to re-channel her resources towards productivity and not bureaucracy. The national resources should be channeled towards creating productive jobs and industrialization. The importation of foreign goods should be restricted to what is necessary to give indigenous industries the opportunity to strive.

\section{Poor Infrastructure}

Development and diversification of Nigerian economy face the challenge of poor economic and social infrastructure. Bad road network, erratic power supply, scarce potable water, poor healthcare facilities, poor transportation and communication network, scarcity of investible fund, and poor and unstable educational system are among the main constraints to economic development and diversification of the economy. The nation needs to invest its resources wisely on technological development, skill acquisition and human development, and provision of economic and social infrastructure for her to be on the path of sustainable development. Improved infrastructure will create ample opportunity for her population to be innovative and productive which will boast production of goods and service for both local consumption and export.

\section{Poor Corporate Governance and Institutions}

To kick-start the economy, the government needs to be seriously committed to the course. There is poor state of corporate governance and institutions in the country due to poor ethical standards in both public and private organizations which frustrate the achievement of the goals of different economic and social policies. Nigerian government has over and over resolved to embark on economic development and diversification but most of the policies yielded marginal effect as they were truncated along the course due to weak institutions and political instability occasioned by personal and sectional interests. 


\section{Endemic Corruption and Mismanagement of Resources}

The endemic nature of corruption in Nigeria makes it very difficult to effectively manage the nation's economy and sustain any policy that will transform the economy. The economy and its policies are corruptibly sabotaged to satisfy individual or sectional interests. The huge earnings of the nation end in private hands. They do not make significant impact on the living standard of the people or on the economic fortune of the nation. Nigeria is a place where there are millionaires and billionaires who have no line of business but are only friends to the government. They employ no body and produce nothing to justify their wealth. It is the endemic corruption that denies the nation the most needed revenue for infrastructural and economic development.

\section{Poor and Unstable Educational System}

The Nigerian educational system is tailored to bureaucracy and not to productivity. Nigerian educational system produces educated graduates without skills. Certificate acquisition is treasured above skill and productivity. It is unfortunate that the nation is playing down skill acquisition and technological institutions for universities. This has led to massive pool of unemployed graduates which continue to strain the economy. The educational system needs to be restructured to produce the right graduates with requisite skills for the economy. Again, the educational system has to be well funded to create the enabling environment for academic exercise and put an end to incessant disruptions of academic activities.

\subsection{Theoretical Framework}

This section of the work deals with a brief review of economic growth theory and recent related studies. The review was taken in order to gain more insight into the scope of the research in the related field.

\section{The Neo-Classical Growth Model (NGM)}

To understand the neo-Classical growth Model, it will be judicious to first comprehend the meaning of economic growth. Economic growth is simply one of the four macroeconomic goals of any society. Simply defined, it refers to the increase overtime of an economy's capacity to produce those goods and services needed to improve the wellbeing of the citizen in increasing numbers and diversity. It is the steady process by which the production capacity of the economy is increased overtime to bring about rising levels of national income (Egunjobi 2012). Thus, this research employs the neo-classical growth model to gain more insight into the scope of the work.

The neo-classical growth mode attributed essentially to the works of Robert Solow attempted to correct a major defect of the Harrod-Domar growth model, that defect being the rigidity of the model imparted to it by the underlying Leontief type production function. This type of production is characterized by fixed capital-labour proportions. This fixity eliminates the possibility of increasing output by increasing the supply of one factor alone. In other words, the scope of factor substitution (diversification) is zero implying the impossibility of factor substitution.

It is this defect inherent in the Harrod-Domar growth model that the neo-classical growth model proceeded to redress. In doing this, the assumption of a Leontief type production function was dropped and replaced by a more realistic production function characterized by well-behaved negatively sloping isoquants. This production function was considered more realistic as it recognized the possibility of factor substitution.

The elegance of this production function was its permission of a variation in the capital output ratio $k$. Thus, an inequality between $s / k$ and $n$ i.e. $s / k=n$ could be corrected by an alteration in $k$. Hence for example, sk>n implies that the capital stock grows at a slower rate than the labour force. When this happens, the capital output ratio, $\mathrm{k}$ will fall thus raising $\mathrm{s} / \mathrm{k}$ and restoring the equality of $\mathrm{s} / \mathrm{k}$ and $\mathrm{n}$ in the process. Conversely, $s / k>n$ implies that the capital stock growth rate outstrips the labour force growth rate as well as the output growth rate. The resulting rise in the capital-output ratio $\mathrm{k}$ will bring about a fall in the $\mathrm{s} / \mathrm{k}$ ratio thus again restoring the equality between $\mathrm{s} / \mathrm{k}$ and $\mathrm{n}$. Therefore, the neo-classical growth model as opposed to its Harrod-Domar growth model counterpart thrives on the possibility of correcting any discrepancy between the warranted and natural growth rates through changes in capital output ratio, $\mathrm{k}$. 
Like the Harrod-Domar growth model, the neo-classical growth model implies that the part and speed of an economy's growth are endogenous policy variables that are within the ambit of policy makers and not homogenous policy. This therefore, implies that Nigerian policy makers should make every urgent effort to encourage diversification of our resources (endogenous) and not encouraging mono-economy which is (homogenous).

\subsection{Empirical Review}

Studies and mathematical models have shown that maintaining a well- diversified economy will yield the most cost-effective level of risk reduction and economic growth in a country.

Hisch (2011) in describing economic diversification as an act of investing in a variety of assets mentioned its benefit as that which reduces risk especially in the time of recession, inflation, deflation etc. Economic diversification strives to smooth out unsystematic risk events in a portfolio so that the positive performance of some investments will neutralize the negative performance of others.

An empirical example relating economic diversification to risk reduction and economic growth was a research carried out by Lorie et al. (2013). They worked out an empirical example of the gains from economic diversification. Their approach was to consider a population of 3,290 securities available for possible inclusion in a portfolio, and to consider the average risk over all possible randomly chosen $n$-asset portfolios with equal amounts held in each included asset, for various values of n. Muttaka (2015), Jorgenson and Stiroh (2015) and Olomola (2015) used endogenous growth model to study the implication of growth rebound in the US economy. Their findings support the assertion of improving economic diversification through other means like information technology which they see as the main sources of the rebound; hence the role of technological progress in agriculture cannot be underestimated.

Other researchers like Oliner and Sichel, (2016) applied the same framework and discovered that the higher growth of output in the newly industrialized countries of East Asia than the rest of the world is almost entirely due to rising in economic diversification which increases labour force participation and empowerment in labour quality (through knowledge accumulation) and not attributable to rapid technological progress. Onucheyo (2012) noted this when he said that the neglect of agriculture and the rural economy and the concentration of economic activity in the oil sector was the cause of the current scarcity of raw materials, which has led to heavy imports of raw materials and foodstuff. Oriakhi and lyola, (2013) examined the effect of Nigeria's oil dependency on economic growth. He observed that Nigeria has wasted much of its opportunities to break away from underdevelopment despite its massive natural and human resources endowment due to heavy reliance on her huge crude oil resources, regrettably mismanaged, as the major source of revenue. He identified and discussed on some key drivers of economic diversification such as investment, governance and regional dimensions of economic diversification as well as human and natural resources. He maintained that of all the other drivers, good governance remains a prerequisite in building an enabling environment for such diversification. Samuelson, (2014) earlier predicted the fall in oil prices, when he pointed out that in the $21^{\text {st }}$ century nuclear, solar, geothermal and other energy sources will be sufficiently developed to meet most of the world's energy requirements. A situation which, according to Samuelson, raises fears for Nigeria's oil powered mono- cultural economy. Samuelson maintained that Nigeria's position in the $21^{\text {st }}$ century will not depend on its oil, but the development of its agricultural sector and related human resources.

Statman (2016) assessed the impact of urban unemployment on economic growth using co-integration and the error correction mechanisms. The research was of the opinion that income, government expenditure and investment in human resources had direct impact while urban-unemployment rate had an indirect impact on economic growth. Hence, he recommended investment in human resources.

Nonetheless, this research has really filled a knowledge gap by studying two important macroeconomic variables: agriculture and human resources/capital management in Nigeria with neo-classical model of growth which concentrates on various activities that will continually raise potential output, causing a shift in the long run aggregate supply. The theory has, in addition, demonstrated that capital deepening in one sector alone cannot lead to continual shifts in the potential output in the long run. Other researches already carried out were done with variables like agriculture or human resources separately, but this study has filled a gap by combining the two variables. Hence, agriculture and human resources management is 
needed to compliment capital for the inducement of growth in the long run and increase in the standard of living.

\section{Methodology of research}

The study was to evaluate the effective approaches to diversifying policy management: The way forward. The population consists of 562 employees of Dangote group of company in Enugu State. The study used the survey approach. The primary sources used were used to administer 290 copies of questionnaire to the sampled staff of Dangote Groups in Enugu, 282 were returned and accurately filled. The validity of the instrument was tested using content analysis and the result was good. The reliability was tested using the Pearson correlation coefficient ( $r$ ). It gave a reliability co-efficient of 0.87 which was also good. The hypotheses were analyzed using f-statistics (ANOVA).

\section{Data presentation and analysis}

Table 1. Response on effect of the various approaches to diversifying policy management on Nigerian business environment

\begin{tabular}{|cc|c|c|c|c|}
\hline & & Frequency & Percent & Valid Percent & Cumulative Percent \\
\hline Valid & SA & 96 & 34.0 & 34.0 & 34.0 \\
& A & 98 & 34.8 & 34.8 & 68.8 \\
& UD & 3 & 1.1 & 1.1 & 69.9 \\
& D & 27 & 9.6 & 9.6 & 79.4 \\
& SD & 58 & 20.6 & 20.6 & 100.0 \\
& Total & 282 & 100.0 & 100.0 & \\
\hline
\end{tabular}

From Table 1, 96 respondents representing 34 percent strongly agree that the various approaches to diversifying policy management affects Nigerian business environment. 98 respondents representing 34.8 percent agree, 3 respondents representing 1.1 percent were undecided, 27 respondents representing 9.6 percent disagree while 58 respondents representing 20.6 percent strongly disagree.

Table 2. Response on the effect of diversifying policy management on the development of Nigeria economy

\begin{tabular}{|ll|c|c|c|c|}
\hline & Frequency & Percent & Valid Percent & Cumulative Percent \\
\hline Valid & SA & 100 & 35.5 & 35.5 & 35.5 \\
& A & 89 & 31.6 & 31.6 & 67.0 \\
& UD & 4 & 1.4 & 1.4 & 68.4 \\
& D & 32 & 11.3 & 11.3 & 79.8 \\
& SD & 57 & 20.2 & 20.2 & 100.0 \\
& Total & 282 & 100.0 & 100.0 & \\
\hline
\end{tabular}

From Table 2, 100 respondents representing 35.5 percent strongly agree that diversifying policy management has significant effect on the development of Nigeria economy. 89 respondents representing 31.6 percent agree, 4 respondents representing 1.4 percent were undecided, 32 respondents representing 11.3 percent disagree while 57 respondents representing 20.2 percent strongly disagree.

\subsection{Test of hypotheses}

Hypotheses one: There are no qualitative approaches to diversifying policy management in Nigeria

Table 3. Model Summary

\begin{tabular}{|c|c|c|c|c|}
\hline Model & $\mathbf{R}$ & R Square & Adjusted R Square & Std. Error of the Estimate \\
\hline 1 & $.988(\mathrm{a})$ & .976 & .976 & .23643 \\
\hline
\end{tabular}

a. Predictors: (Constant), DVST, EGT, PAT 
Table 4. ANOVA(b)

\begin{tabular}{|cc|c|c|c|c|c|}
\hline Model & & Sum of Squares & df & Mean Square & F & Sig. \\
\hline 1 & Regression & 648.720 & 1 & 648.720 & 11604.746 & $.000(\mathrm{a})$ \\
& Residual & 15.652 & 280 & .056 & & \\
& Total & 664.372 & 281 & & & \\
\hline
\end{tabular}

a Predictors: (Constant), DVST, EGT, PAT

b Dependent Variable: PMGT,

\subsection{Coefficient of multiple determinants $\left\{r^{2}\right\}$}

The $R^{2}\{R$-Squared $\}$ which measures the overall goodness of fit of the entire regression, shows the value as .976 . This means that $R^{2}$ accounts for 97.6 percent approximately 98 percent. This indicates that the independent variables accounts for about 98 percent of the variation in the dependent variable. Which shows goodness of fit? From the result, f-calculated $\{11606.746\}$ is greater that the $f$-tabulated $\{2.7858\}$, that is, $\mathrm{f}$-cal>f-tab. Hence, we reject the null hypothesis $\{\mathrm{HO}\}$ and accept alternative hypothesis which means that the overall estimate has a good fit which also implies that our independent variables are simultaneously significant. We now conclude from the analysis that there are qualitative approaches to diversifying policy management in Nigeria.

Hypotheses Two: Diversifying policy management does not play any significant role on the development of Nigeria economy

Table 5. Model Summary

\begin{tabular}{|c|c|c|c|c|}
\hline Model & $\mathbf{R}$ & R Square & Adjusted R Square & Std. Error of the Estimate \\
\hline 1 & $.915(\mathrm{a})$ & .836 & .836 & .64484 \\
\hline
\end{tabular}

a Predictors: (Constant), EGRT, GDP, NNI

Table 6. ANOVA(b)

\begin{tabular}{|cc|c|c|c|c|c|}
\hline Model & & Sum of Squares & Df & Mean Square & F & Sig. \\
\hline 1 & Regression & 595.188 & 1 & 595.188 & 1431.372 & $.000(\mathrm{a})$ \\
& Residual & 116.429 & 280 & .416 & & \\
& Total & 711.617 & 281 & & & \\
\hline
\end{tabular}

(a) Predictors: (Constant), EGRT, GDP, NNI

(b) Dependent Variable: DVST

\subsection{Coefficient of multiple determinants $\left\{r^{2}\right\}$}

The $R^{2}\{R$-Squared $\}$ which measures the overall goodness of fit of the entire regression, shows the value as .83.6. This means that $R^{2}$ accounts for 83.6 percent approximately 84 percent. This indicates that the independent variables accounts for about 84 percent of the variation in the dependent variable. Which shows goodness of fit? From the result, f-calculated $\{1431.372\}$ is greater that the f-tabulated $\{2.7858\}$, that is, f-cal>f-tab. Hence, we reject the null hypothesis $\{\mathrm{HO}\}$ and accept Alternative hypothesis which means that the overall estimate has a good fit which also implies that our independent variables are simultaneously significant. We now conclude from the analysis that diversifying policy management plays significant role in the development of Nigeria economy.

\section{Conclusions and Recommendations}

The result of this study has shown that there are qualitative approaches to diversifying policy management in Nigeria. The study also shows that diversifying policy management plays significant role in the development of Nigeria economy. Economic diversification is the process of expanding the range of economic activities both in the production and distribution of goods and services. It is the widening of the economy to create opportunities for diverse economic activities to create a broad based economy. It provides job for wide spectrum of people and stabilizes the economy against economic fluctuations of commodities, and sustains the developmental prospects of nations. Nigeria needs to use her huge oil revenue to diversify her economy to create job opportunities and satisfy the basic needs of her large 
population and sustain her quest for development. To achieve this, she has to conscientiously confront the challenges that hinder her economic diversification to reposition herself on the path of productivity. These challenges make industrial investment in the country very expensive and unattractive.

Diversified economy will stabilize Nigeria's economy against the vagaries of oil market, and provide opportunities for the satisfaction of needs and aspirations of her population. Different sections of the nation and tiers of government should develop other aspects of economy where they have comparative advantage. The efforts should accommodate the key requirements of sustainable development which include meeting the basic needs of man (job, food, health, clothing and shelter), maintaining equity both within and between generations, improving on technology and social organization to expand the environmental ability to sustain human needs.

\section{References}

1. Adebayo, O.O. (2012). Nigeria External Debt Crisis: Its Management, Lagos: Malt house Press.

2. Limited \& Akpan, E.O. (2015). Oil Price Shocks and Nigeria's Macro Economy. [Online]. Available:http://www.csae.ox.ac.uk/conferences/2009-EDiA/papers/252-Akpan.pdf

3. Brown, P. L. (2014). Nigeria, the mono-economy, The Leadership Newspaper, 1-5.CIA Fact book (2013) and NPC annual report (2012).

4. Egunjobi, T.A. (2012). Impact of unemployment and poverty on economic growth in Nigeria.

5. Hisch, C. (2011). What explains the industrial revolution in East Asia? Evidence from factor markets.

6. Jorgenson, D.W. \& Stiroh, K. J. (2015). Raising the speed limit versus economic growth in the information age. [Unpublished paper]. USA: Harvard University.

7. Lorie, J., Dodd, P. \& Kimpton, M. (2013). The stock market: Theories and evidence, $\left(2^{\text {nd }}\right.$ ed,). USA: McGraw Hill College.

8. Muttaka, M. (2015). The intrigues of Nigeria's diversification strategy. [Online].

9. Oliner,S.D. \& Sichel, D. E. (2016). The resurgence of growth in the late 1990s: Is information technology the story? Federal Reserve Board, Finance and Economics Discussion Series, 20.

10. Olomola, P.A., (2015). Oil price shock and aggregate economic activity in Nigeria, African Economic and Business Review, 4 (2).

11. Onucheyo (2012). Agriculture and the economic future of Nigeria. Available: http://www.wazobia. biafranigeria.com/

12. Oriakhi, D.E. \&lyola, D.O. (2013). Oil price volatility and its consequences on the growth of the Nigerian economy: An examination. Asian Economic and Financial Review, 5 (3): 683-70.

13. Samuelson, P. (2014). Risk and uncertainty: A fallacy of large numbers, Scientia, 98:108-113.

14. Samuelson, P. (2013). General Proof that diversification pays, Journal of Financial and Quantitative Analysis, 2: 1-13.

15. Statman, M., (2016) How many stocks make a diversified portfolio? The Journal of Financial and Quantitative Analysis, 22(3): 353-36[Online]. Available: http://www.jstor.org/stable/2330969

16. Sullivan, A. \& Steven, M. S. (2012). Economics: Principles in action. Upper Saddle River, New Jersey: Pearson Prentice Hall.

17. Ross, S. (2018). Adding risks: Samuelson's fallacy of large numbers revisited, Journal of Financial and Quantitative Analysis, 34: 323-339.

18. Todaro, M. P. \& Smith, S. C. (2017). Economic Development, (10 ${ }^{\text {th }}$ ed.). Singapore: Pearson Education.

19. Udoh, B. (2014). Dwindling oil price: CBN devalues naira, raises lending rate. Premium Times Newspaper, Nigeria.

20. Whelan, K. (2016). Computers, obsolescence and productivity. Federal Reserve Board, Finance and Economics Discussion Series paper No. 20.

21. Young, A. (2017). The tyranny of numbers: Confronting the statistical reality of the East Asian growth experience. Quarterly Journal of Economics, 110: 641-680. 